\title{
Big cats in borderlands: challenges and implications for transboundary conservation of Asian leopards
}

\author{
Mohammad S. Farhadinia, Susana Rostro-García, Limin Feng \\ Jan F. Kamler, Andrew Spalton, Elena Shevtsova, Igor Khorozyan \\ Mohammed Al-Duais, Jianing Ge and David W. Macdonald
}

\begin{abstract}
Large carnivores have extensive spatial requirements, with ranges that often span geopolitical borders. Consequently, management of transboundary populations is subject to several political jurisdictions, often with heterogeneity in conservation challenges. In continental Asia there are four threatened leopard subspecies with transboundary populations spanning 23 countries: the Persian Panthera pardus saxicolor, Indochinese $P$. pardus delacouri, Arabian P. pardus nimr and Amur P. pardus orientalis leopards. We reviewed the status of these subspecies and examined the challenges to, and opportunities for, their conservation. The Amur and Indochinese leopards have the majority $(58-100 \%)$ of their remaining range in borderlands, and the Persian and Arabian leopards have $23-26 \%$ of their remaining ranges in borderlands. Overall, in 18 of 23 countries the majority of the remaining leopard range is in borderlands, and thus in most countries conservation of these subspecies is dependent on transboundary collaboration. However, we found only two transboundary initiatives for Asian leopards. Overall, we highlighted three key transboundary landscapes in regions that are of high importance
\end{abstract}

Mohammad S. Farhadinia (Corresponding author, (1) orcid.org/0000-00025385-6254) Oxford Martin School and Department of Zoology, University of Oxford, 34 Broad Street, Oxford OX1 3BD, UK

E-mail mohammad.farhadinia@zoo.ox.ac.uk

Susana Rostro-García, Jan F. Kamler ${ }^{*}$ and David W. Macdonald Department of Zoology, Wildlife Conservation Research Unit, University of Oxford, Oxford, UK

Limin Feng and JianPing Ge Northeast Tiger and Leopard Biodiversity National Observation and Research Station, Monitoring and Research Center for Amur Tiger and Amur Leopard, National Forestry and Grassland Administration, Ministry of Education Key Laboratory for Biodiversity Science and Engineering \& College of Life Sciences, Beijing Normal University, Beijing, China

Andrew Spatton Office of the Minister, Diwan of Royal Court, Muscat, Oman Elena Shevtsova Federal Government Budgetary Institution United Administration of the State Nature Biosphere Reserve Kedrovaya Pad and Land of the Leopard National Park, Ministry of Natural Resources and Environment of the Russian Federation, Vladivostok, Russia

IGOR KHOROZYAN Georg-August-Universität Göttingen, Göttingen, Germany

Moнammed AL-Duais Foundation Endangered Wildlife \& Department of Biology, Ibb University, Ibb, Republic of Yemen

${ }^{*}$ Also at: Panthera, New York, USA

Received 14 February 2019. Revision requested 17 April 2019.

Accepted 4 June 2019. First published online 19 June 2020. for the survival of these subspecies. Recent listing of the leopard in the Bonn Convention on the Conservation of Migratory Species of Wild Animals is important, but more international collaboration is needed to conserve these subspecies. We provide a spatial framework with which range countries and international agencies could establish transboundary cooperation for conserving threatened leopards in Asia.

Keywords Asia, Bonn Convention on the Conservation of Migratory Species of Wild Animals, borderland, conservation geopolitics, leopard, Panthera pardus, security fence, transboundary

\section{Introduction}

T arge carnivores have extensive spatial requirements that $\_$may extend beyond geopolitical borders. Consequently, these wide-ranging animals can fall under several political jurisdictions, resulting in a diversity of conservation challenges and efforts (Bischof et al., 2016; Linnell et al., 2016). Neighbouring states may have different levels of technical expertise, knowledge, capacity and financial resources (Karlstetter \& Mallon, 2014). Importantly, persistence of large carnivore populations in one country can depend, because of source-sink dynamics, on populations on the other side of an international border (Falcucci et al., 2013; Farhadinia et al., 2015; Feng et al., 2017). Conservation of large carnivores requires a holistic appreciation of the geopolitical context (Hodgetts et al., 2019) for maintaining source populations as a priority and, where possible, enhancing links to ensure persistence of metapopulations.

Although geopolitical borderlands are typically rich in biodiversity, protecting these landscapes is often challenging. National conservation programmes usually stop at international borders, but the species they aim to conserve and the threats they strive to halt often do not (Macdonald et al., 2018). Borderlands are characterized by dynamic social, political, economic and sometimes even ecological transitions that, at extremes, may involve armed conflict and political instability (McNeely, 2003). Man-made barriers along geopolitical borders, intended to control 
movement of people, can create an impediment for the movement of large carnivores (Karlstetter \& Mallon, 2014; Linnell et al., 2016; Trouwborst et al., 2017). Expansion of border security barriers is recognized as a threat to wildlife because they can cause mortality, obstruct access to seasonally important resources, and reduce effective population size and viability (Linnell et al., 2016). Range shifts across political borders induced by global climate change are also potential challenges for many species (Hannah, 2010). These challenges can add to the already precarious circumstances of many large carnivores, which often occur at low densities and are prone to demographic and environmental stochasticity.

Although its broad geographical range and charismatic appeal make the leopard Panthera pardus one of the most potent mammalian ambassador species, it is experiencing a greater range loss than most other large terrestrial carnivores (Wolf \& Ripple, 2017). In Asia, leopard subspecies currently occur in $<16 \%$ of their historical range, with the only relatively large populations (400-500 individuals) occurring in India, Sri Lanka and Iran (Jacobson et al., 2016; Stein et al., 2016). Persistence of many small populations of leopards is dependent on source-sink dynamics across international borders (Khorozyan et al., 2014; Farhadinia et al., 2015; Rostro-García et al., 2016; Feng et al., 2017; Maharramova et al., 2018; Askerov et al., 2019).

Various international legal instruments exist that have a direct or indirect effect on the conservation of large carnivores, including the 1979 Bonn Convention on the Conservation of Migratory Species of Wild Animals (Karlstetter \& Mallon, 2014; Trouwborst et al., 2017). The Convention has evolved into an instrument focusing on the conservation of migratory wildlife crossing international borders (Trouwborst et al., 2017). Recent listing of the leopard in Appendix II of the Convention is a step towards initiating global or regional agreements for the conservation and management of this species. However, it is not yet clear what regional and global challenges are faced by leopard conservation in Asia and what opportunities exist for overcoming them.

Here, we highlight the importance of implementing transnational strategies for the conservation of leopards that range across extensive areas in continental Asia. We focus on the conservation status and challenges of transboundary populations of threatened leopard subspecies, and identify initiatives with which conservation practitioners can facilitate effective transboundary cooperation for the conservation of leopards, and perhaps also other large mammals.

We reviewed the available literature to collate a dataset of the population size and distribution of each threatened subspecies in Asia (Jacobson et al., 2016; Stein et al., 2016), and the legal status of the leopard in each country. The spatial metrics, specifically leopard range (extant and possibly extant) overlapping with borderlands, and length of border lines, were calculated using QGIS 3.2.1 (QGIS Development Team, 2017). We assigned a range patch as transboundary if it overlapped with borderlands, which we defined as a buffer zone of $80 \mathrm{~km}$ from the borderline. We chose this size because it is the maximum dispersal distance for leopards in Asia, recorded for the Persian subspecies using satellite telemetry in north-east Iran (Farhadinia et al., 2018). We acknowledge that this buffer is an approximation, but there are no similar data for the other Asian subspecies.

\section{Transboundary ranges}

There are six leopard subspecies across continental Asia (Jacobson et al., 2016; Stein et al., 2016). We focus on those subspecies that have transboundary populations and are categorized, or are being petitioned to be categorized, as Endangered or Critically Endangered on the IUCN Red List of Threatened Species: the Persian P. pardus saxicolor (Endangered), Indochinese P. pardus delacouri (Critically Endangered), Arabian P. pardus nimr (Critically Endangered), and Amur P. pardus orientalis (Critically Endangered) leopards (Table 1, Plate 1).

\section{Persian leopard}

The Persian leopard occurs across the rugged terrain of 13 countries in western Asia and the Caucasus, with a population of 800-1,00o individuals (Khorozyan, 2008) and $>75 \%$ of the subspecies' extant range within Iran (Jacobson et al., 2016). In 10 countries the Persian leopards' range occurs exclusively in borderlands (Fig. 1, Table 2), with small populations of generally $<10$ individuals (Askerov et al., 2015; Avgan et al., 2016). These appear to be sink populations on the brink of extinction (Askerov et al., 2015; Avgan et al., 2016; Stein et al., 2016; Maharramova et al., 2018), although under intensive conservation efforts they are able to recolonize suitable habitats (Askerov et al., 2019).

\section{Indochinese leopard}

The Indochinese leopard is probably extant in only $2-6 \%$ of its historical distribution in South-east Asia, and the remaining populations are small and isolated (Rostro-García et al., 2019). This subspecies has been extirpated in Singapore, probably extirpated in Laos and Viet Nam, nearly extirpated in Cambodia and has a greatly reduced distribution in China, Thailand, Myanmar and Peninsular Malaysia (RostroGarcía et al., 2016). Of the remaining extant and possibly extant distribution, $58 \%$ lies within borderlands (Table 1). With the exception of Malaysia, most of the remaining leopard range within each country is in borderlands (Fig. 1, Table 2). 
TABLE 1 Details of an Endangered and three Critically Endangered leopard Panthera pardus subspecies with populations in borderlands of continental Asia.

\begin{tabular}{llllr}
\hline Subspecies & $\begin{array}{l}\text { No. of extant } \\
\text { range countries }\end{array}$ & $\begin{array}{l}\text { Borderline } \\
\text { length }(\mathrm{km})\end{array}$ & $\begin{array}{l}\text { Total area of subspecies } \\
\text { range }\left(\mathrm{km}^{2}\right)\end{array}$ & $\begin{array}{l}\text { Borderland area, } \mathrm{km}^{2}(\% \text { of } \\
\text { subspecies overall range })\end{array}$ \\
\hline $\begin{array}{l}\text { Endangered } \\
\text { Persian P. pardus saxicolor }\end{array}$ & 13 & 3,415 & 933,597 & $247,035(26)$ \\
$\begin{array}{l}\text { Critically Endangered } \\
\text { Indochinese P. pardus delacouri }\end{array}$ & 5 & 1,740 & 159,000 & $92,220(58)$ \\
Arabian P. pardus nimr & 4 & 47 & 22,720 & $5,332(23)$ \\
Amur leopard P. pardus orientalis & 3 & 248 & 9,270 & $9,270(100)$ \\
Total & $23^{1}$ & 5,450 & $1,124,587$ & $353,857(31)$ \\
\hline
\end{tabular}

${ }^{1}$ There are two leopard subspecies in both China and Russia, and therefore the total number of countries is 23 rather than 25.

\section{Arabian leopard}

There are small populations of the Arabian leopard in Oman, Saudi Arabia, Israel, and Yemen (Fig. 1, Table 2). Until relatively recently, this subspecies also occurred in Jordan and the United Arab Emirates, in both of which the populations would have been partly transboundary with Israel and Oman, respectively (Jacobson et al., 2016). The main stronghold for the subspecies is the Dhofar Mountains of Oman, which comprise three contiguous mountain blocks: Jabal Samhan in the east, Jabal Al Qara in the centre and Jabal Al Qamar in the west, the latter contiguous with the mountains of Hawf in southeast Yemen. Occasional records of leopard mortality indicate some small populations across the inner parts of Yemen. The largest population nucleus of up to 30 Arabian leopards is believed to inhabit Jabal Samhan, which is c. $150 \mathrm{~km}$ from the Oman-Yemen border. A further 22-28 leopards occur across Jabal Al Qara and Jabal $\mathrm{Al}$ Qamar, with individuals recorded up to $16 \mathrm{~km}$ from the Oman-Yemen border (Spalton \& Al Hikmani, 2014). Across the Oman-Yemen border in Hawf, leopards were recorded in low numbers in 2011 (Khorozyan et al., 2014). Elsewhere, there are thought to be a few scattered areas of extant range for the Arabian leopard along the border between Yemen and Saudi Arabia (Zafar-ul Islam et al., 2018).

\section{Amur leopard}

There is only one population of the Amur leopard (Fig. 1) shared between Russia's Primorskii Krai and China's Jilin Province (Jacobson et al., 2016; Feng et al., 2017). There are also occasional reports, based on snow tracking, from North Korea (Jacobson et al., 2016). With no evidence of Amur leopards occurring elsewhere, this single transboundary population of 70-108 individuals represents the global population of this subspecies (Vitkalova et al., 2018). After concerted conservation effort, the Amur leopard population is increasing in China, and some reproduction has been documented $50 \mathrm{~km}$ from the Russian border (Wang et al., 2016).

\section{Discussion}

The importance of borderlands for leopard conservation

A relatively high proportion (23-100\%) of the ranges of each leopard subspecies occurs in borderlands. The Amur and Indochinese leopards are most dependent on borderlands as the majority of their remaining distribution occurs within these areas. The Persian and Arabian leopards have the majority of their remaining distribution beyond borderlands as most of their populations are within Iran and Afghanistan for the Persian leopard, and Oman and possibly Yemen for the Arabian leopard.

Transboundary conservation initiatives have been endorsed for many of Asian leopard subspecies (Knight et al., 2011; Askerov et al., 2015; Farhadinia et al., 2015; Feng et al., 2017). However, only two transboundary initiatives are actively working to facilitate leopard conservation across borders, in the Caucasus (Askerov et al., 2015) and in the Russian Far East and north-east China (Feng et al., 2017; Vitkalova et al., 2018). Transboundary conservation was not considered in the latest IUCN assessment of leopards (Stein et al., 2016). Our review highlights the importance of encouraging conservation agencies to work across international borders in Asia.

\section{Conservation challenges in borderlands}

Previous studies have highlighted poaching of leopards and their prey, and habitat loss, as the main reasons for the decline of leopards across most of their range in Asia (Farhadinia et al., 2015; Jacobson et al., 2016; Rostro-García et al., 2016; Wang et al., 2016; Zafar-ul Islam et al., 2018). We identify four main challenges for the conservation of transboundary populations of Asian leopards: (1) different levels of legal 

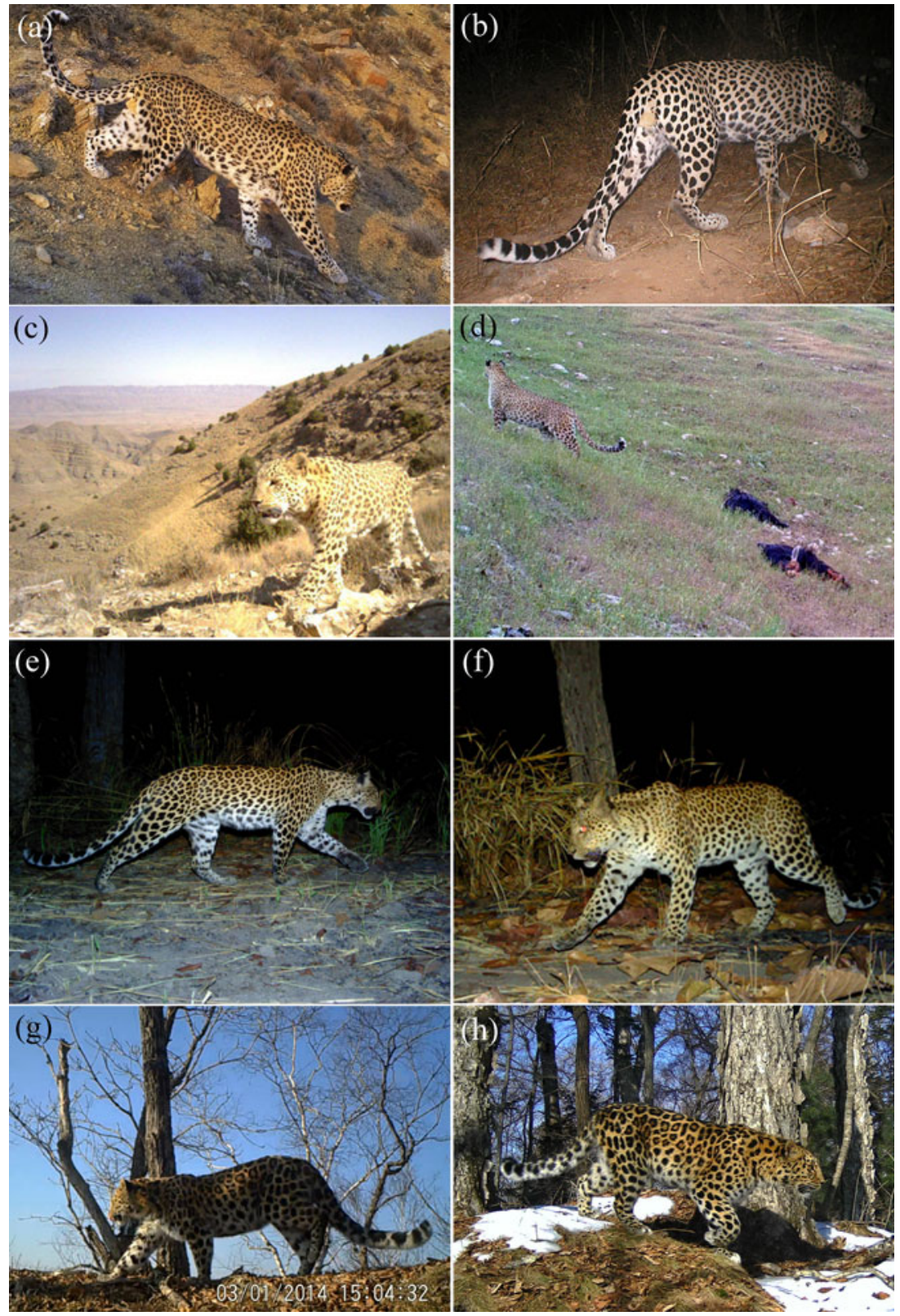

Plate 1 Photographic evidence of Asian leopards in borderlands: (a) Persian leopard $P$. pardus saxicolor with amputated leg along the Armenia-Azerbaijan-Iran border in the Caucasus (Photo: WWF), (b) an Arabian leopard P. pardus nimr in the Hawf, on the Yemen-Oman border (Photo: Foundation for Endangered Wildlife Yemen), (c) a Persian leopard in north-east Iran, with Turkmenistan's mountains in the background (Photo: WildCRU/ Future4Leopards Foundation), (d) a Persian leopard after killing two domestic goats along the Iran-Iraq border (Photo: Iran Department of Environment/R. Khoshfarman), (e, f) Indochinese leopards $P$. pardus delacouri near the CambodiaViet Nam border (Photo: Panthera/ WildCRU/WWF Cambodia/Ministry of Environment), and Amur leopards $P$. pardus orientalis along the Russia-China border in (g) China (Photo: Beijing Normal University) and (h) Russia (Photo: FGBU/ Land of the Leopard). protection and management across national jurisdictions, (2) military activities and armed conflict, (3) poaching for illegal international wildlife trade and (4) infrastructure projects, such as road development.

There are varied levels of legal protection and management for leopards across national jurisdictions and protection by law across most range countries, with substantial monetary fines and/or imprisonment for illegal killing (Table 2). However, there were time lags of several decades for legal protection in the adjacent countries in several large borderland populations, such as Thailand-Myanmar and Iran-Iraq-Turkey (Table 2). Neighbouring countries may have different agendas, technical capacities, and resources available for leopard conservation, potentially hindering the recovery of transboundary populations. For example, the governments of Turkmenistan,
Kazakhstan and Afghanistan (Persian leopard) and Cambodia, China, Myanmar and Laos (Indochinese leopard) have not prioritized or supported conservation action plans for the leopard, which hampers conservation efforts made by neighbouring states. In Oman, conservation of the Arabian leopard benefits from strong government agencies, law enforcement and compensation programmes in cases of livestock depredation. In adjacent Yemen, however, where there is an ongoing armed conflict, there is little or no active conservation or protection of leopards.

Military activities and armed conflicts occur within the borderland ranges of all leopard subspecies except for the Amur leopard. Political unrest compromises law enforcement and effective conservation. Potential effects of military activities and armed conflicts on leopards and the 


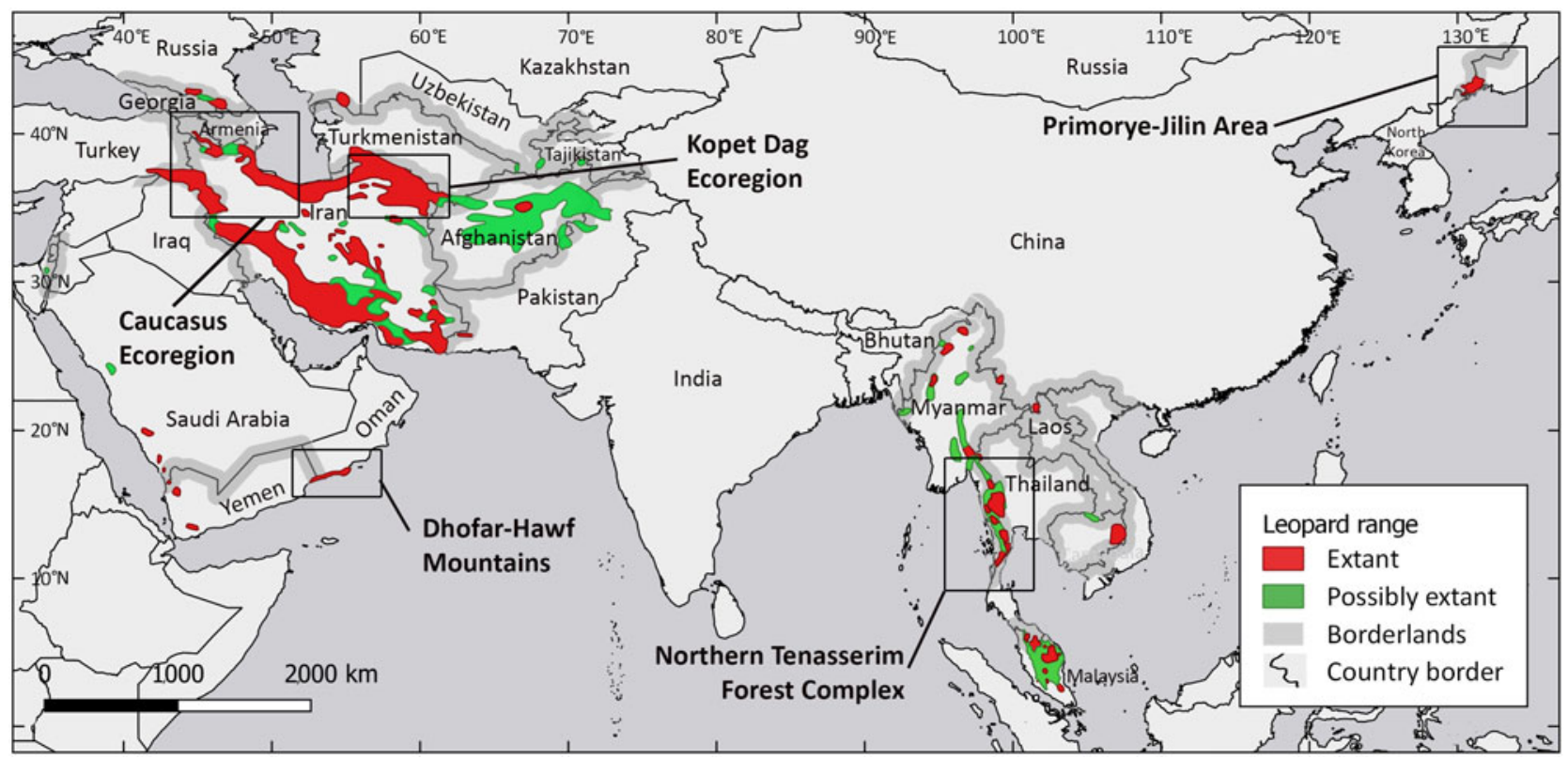

FIg. 1 The current range of the Persian Panthera pardus saxicolor, Arabian P. pardus nimr, Indochinese P. pardus delacouri and Amur $P$. pardus orientalis leopard subspecies in Asia, and the locations of borderlands.

persistence of their prey require further research. The principal conflicts currently affecting leopards are those between Yemen and Saudi Arabia, the Nagorno-Karabakh conflict between Armenia and Azerbaijan, and political instabilities along the borders between northern Iraq, western Iran and Turkey, and between Afghanistan and Pakistan. In Myanmar, the long-running Karen insurgency near the border with Thailand could be negatively affecting a local leopard population (Oswell, 2010), although recent surveys conducted in Karen State found a high diversity of species, including leopards (Moo et al., 2018). Other nongovernment controlled areas in northern Myanmar, along the borders with Thailand, Laos, China and India, play a major role in illicit activities, including poaching and facilitating the illegal trade of leopards and other wild felids (Oswell, 2010). Furthermore, mine-strewn borderlands occasionally kill leopards and other wildlife, including areas along the Thailand-Myanmar, Iran-Iraq and ArmeniaAzerbaijan borders (Oswell, 2010; Avgan et al., 2016; IUCN SSC Cat Specialist Group, 2016).

Illegal wildlife trade, particularly intensive and indiscriminate snaring over large areas, is the main cause of the dramatic decline of the Indochinese leopard (RostroGarcía et al., 2016, 2019). This is particularly problematic in borderlands because poachers may originate from a neighbouring country (O'Kelly et al., 2018) and return across the border before being apprehended. In general, weak enforcement of wildlife laws and lax border security have facilitated the illegal trade of wildlife products in South-east Asia (Oswell, 2010). Two border markets for the trafficking of exotic animals, including the Arabian leopard, are active in Harad and Al Khoba in Yemen and Saudi Arabia, respectively.

Existing and proposed infrastructure projects can have detrimental effects on leopards and other wildlife. For example, road development, which has increased in Asia, has direct negative impacts on wildlife, particularly largebodied mammals such as leopards (Clements et al., 2014). Amongst other impacts, roads can promote illegal wildlife trade, impede animal movement, and be precursors of overhunting and habitat destruction. In Myanmar, a major source of illegal wildlife, road networks have facilitated illegal trade of mammals to border markets (Oswell, 2010). Proposed major infrastructure projects are expected to cause fragmentation of key landscapes, such as the Dawei Special Economic Zone road in the Northern Tenassarim Forest Complex (Helsingen et al., 2015), one of the last strongholds for the Indochinese leopard (Rostro-García et al., 2016) as well as Kopet Dag ecoregion along the Iran-Turkmenistan border for the Persian leopard (Farhadinia et al., 2019). Because development projects are increasing throughout many areas of Asia, it is imperative that measures are taken to minimize the impact that such projects have on leopards and other wildlife.

Border security fencing and associated roads are concerns for transboundary movement of wildlife in many parts of Eurasia (Linnell et al., 2016). Although barbed wire is common in some range country borderlands, such as parts of the Caucasus region, it is unlikely to act as a barrier for leopard movement, but more impassable border fences may impede movements of leopards and their prey along the Iran-Turkmenistan and Yemen-Oman borders (Fig. 2). 
TABLE 2 Populations and legal status of the four threatened leopard subspecies across continental Asia.

\begin{tabular}{|c|c|c|c|c|c|}
\hline $\begin{array}{l}\text { Extant } \\
\text { countries }\end{array}$ & $\begin{array}{l}\text { Year national pro- } \\
\text { tection granted }\end{array}$ & Fine for illegal killing (USD) & $\begin{array}{l}\text { Population } \\
\text { size }\end{array}$ & $\begin{array}{l}\% \text { country range } \\
\text { in borderlands }\end{array}$ & $\begin{array}{l}\text { Reference for popula- } \\
\text { tion size }\end{array}$ \\
\hline \multicolumn{6}{|l|}{ Persian leopard } \\
\hline Afghanistan & 2008 & None & $200-300$ & 18 & Khorozyan (2008) \\
\hline Armenia & 1972 & $\begin{array}{l}6,100 \text { (outside protected area), } \\
30,500 \text { (inside protected area) }\end{array}$ & $<10$ & 100 & Askerov et al. (2015) \\
\hline Azerbaijan & 1976 & $\begin{array}{l}1,950 \text { (outside protected area), } \\
5,820 \text { (inside protected area) }\end{array}$ & $<10$ & 100 & Askerov et al. (2015) \\
\hline Georgia & 1982 & 19,000 & $<3$ & 100 & Askerov et al. (2015) \\
\hline Iran & 1965 & 9,200 & $550-850$ & 28 & Kiabi et al. (2002) \\
\hline Iraq & 2010 & 8,350 & $<10$ & 100 & Avgan et al. (2016) \\
\hline Kazakhstan & 2004 & 9,220 & Not known & 100 & \\
\hline Pakistan & Not known & Not known & Not known & 75 & \\
\hline Russia & 1956 & $\begin{array}{l}2-9 \text { years in prison plus a fine } \\
\text { up to } 45,700\end{array}$ & $<10$ & 100 & Khorozyan (2008) \\
\hline Tajikistan & 2008 & $424-25,000$ & Not known & 100 & \\
\hline Turkey & 2003 & 13,600 & $<10$ & 100 & Avgan et al. (2016) \\
\hline Turkmenistan & $1970 s$ & $\begin{array}{l}600 \text { (outside protected area), } \\
1,700 \text { (inside protected area) }\end{array}$ & $<60$ & 91 & $\begin{array}{l}\text { O. Pereladova, pers. } \\
\text { comm. (2020) }\end{array}$ \\
\hline Uzbekistan & 1983 & $\begin{array}{l}7,300 \text { (for Uzbek citizens), } \\
40,000 \text { (for foreign citizens) }\end{array}$ & Not known & 100 & Not known \\
\hline \multicolumn{6}{|c|}{ Indochinese leopard } \\
\hline Cambodia & 1994 & Up to 24,500 & $18-178$ & 100 & $\begin{array}{l}\text { Modified from } \\
\text { Rostro-García et al. } \\
(2019)\end{array}$ \\
\hline Malaysia & 1972 & $\begin{array}{l}24,000-120,000, \text { depending } \\
\text { on age/sex of leopard }\end{array}$ & $106-1,059$ & 26 & $\begin{array}{l}\text { Modified from } \\
\text { Rostro-García et al. } \\
(2019)\end{array}$ \\
\hline Myanmar & 1994 & Up to 7,680 & $169-1,693$ & 59 & $\begin{array}{l}\text { Modified from } \\
\text { Rostro-García et al. } \\
(2019)\end{array}$ \\
\hline SE China & 1988 & $\begin{array}{l}>10 \text { years in prison plus a } \\
\text { fine }(1,600) \text { or confiscation } \\
\text { of property }\end{array}$ & Not known & 100 & \\
\hline Thailand & 1960 & Up to 1,200 & $59-591$ & 98 & $\begin{array}{l}\text { Modified from } \\
\text { Rostro-García et al. } \\
(2019)\end{array}$ \\
\hline \multicolumn{6}{|c|}{ Arabian leopard } \\
\hline Israel & Not known & Not known & 8 & 100 & Perez et al. (2006) \\
\hline Oman & 1976 & Up to 12,500 & $44-58$ & 25 & $\begin{array}{l}\text { Spalton \& Al Hikmani } \\
\text { (2014) }\end{array}$ \\
\hline Saudi Arabia & 1999 & $\begin{array}{l}5,000 \text { (outside protected area), } \\
13,000 \text { (inside protected area) }\end{array}$ & $<50$ & 6 & $\begin{array}{l}\text { Zafar-ul Islam et al. } \\
(2018)\end{array}$ \\
\hline Yemen & 2009 & Not known & Not known & 37 & \\
\hline \multicolumn{6}{|c|}{ Amur leopard ${ }^{1}$} \\
\hline NE China & 1988 & $\begin{array}{l}>10 \text { years in prison plus a } \\
\text { fine }(1,600) \text { or confiscation } \\
\text { of property }\end{array}$ & $70-108$ & 100 & Vitkalova et al. (2018) \\
\hline North Korea & Not known & Not known & Not known & 100 & \\
\hline Russia & 1956 & $\begin{array}{l}2-9 \text { years in prison plus a fine } \\
\text { up to } 45,700\end{array}$ & $70-108$ & 100 & Vitkalova et al. (2018) \\
\hline
\end{tabular}

${ }^{1}$ Population size is the total number across Russia and China.

${ }^{2} \mathrm{An}$ increase up to USD 207,600 is currently under consideration. 


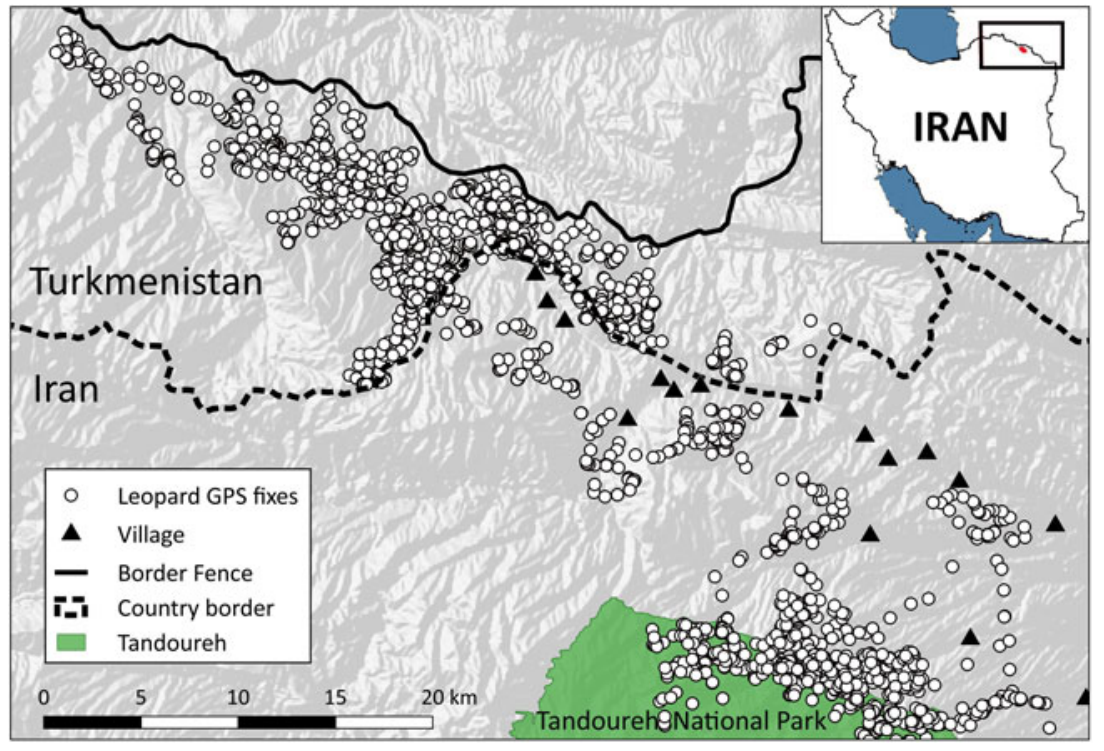

FIG. 2 Locations (from GPS fixes) of a collared Persian leopard that dispersed from Tandoureh National Park in north-east Iran to Turkmenistan (Farhadinia et al., 2018). The locations show that although the leopard moved freely across the international border, the security fence, which lies further north within Turkmenistan, was a barrier to the leopard's movements.
Most borderland leopard populations in Asia occur along unfenced borders, and thus transboundary movements are still feasible.

For leopards that move freely across international borders in Asia, the same individuals may be counted in more than one country, inflating abundance estimates (Bischof et al., 2016; Vitkalova et al., 2018). This may be a problem in the Caucasus and along the Russia-China border (Vitkalova et al., 2018; Askerov et al., 2019). This emphasizes the need for the establishment of internationally managed monitoring programmes and for sharing monitoring information. Transboundary information exchange can improve the accuracy and precision of population estimates, which can lead to a better understanding of the status of leopard populations.

\section{Implications for policy}

Transboundary conservation areas are widely recommended as a means to encourage multilateral intergovernmental partnerships. The concept of international Peace Parks is being promoted as a way of linking biodiversity conservation with national security (McNeely, 2003), and such a park has been established between Arevik National Park in Armenia and Dizmar Protected Area in Iran, where leopards occur. In addition to the two existing transboundary leopard initiatives in the Caucasus and Russia-China borderlands (Vitkalova et al., 2018; Askerov et al., 2019), we identified three key transboundary landscapes: (1) Kopet Dag ecoregion along the Iran-Turkmenistan border for the Persian leopard, although some parts contain impassable fences (Fig. 2), (2) Northern Tenasserim Forest Complex along the Thailand-Myanmar border for the Indochinese leopard, one of WWF's five priority global landscapes (WWF, 2019), and (3) Hawf-Dhofar Mountains along the Yemen-Oman border for the Arabian leopard. Despite the civil strife in Yemen, the border governorate of Al Mahrah in Yemen adjoining Oman's Dhofar Mountains remainsless affected.

Conservation paradigms need to be realigned with political reality when examining geopolitical situations for conservation (Linnell et al., 2016). Some Asian countries are facing security challenges from neighbouring countries, which could reduce opportunities for transboundary cooperation. Given that the majority of borderland leopard populations occur along unfenced international borders, conflicting countries can unilaterally enforce the conservation of their transboundary populations and shift their conservation investments towards the borderland. An example is leopard conservation in Armenia and Azerbaijan's Nakhichevan Republic which, despite a political dispute, has succeeded in maintaining protected areas for leopards and supporting population recovery on both sides of the shared border (Askerov et al., 2019).

In addition, effects of border fences on leopard movements and demography need to be better understood. If planned without compromising national security, joint population monitoring (Feng et al., 2017; Vitkalova et al., 2018) and satellite telemetry (Farhadinia et al., 2018) can help elucidate the locations of corridors and source-sink dynamics across international borders. Citizen science monitoring schemes supported by border security personnel could provide coarse-scale data to identify key corridors.

There are two intergovernmental organizations, the Association of Southeast Asian Nations (ASEAN) and Economic Cooperation Organization (ECO), of which most of the regional countries within the ranges of the Indochinese and Persian leopard, respectively, are members. The ASEAN Wildlife Enforcement Network and ECO's Division on Social Welfare and Environment could provide a framework for the establishment of transboundary 
cooperation for leopard conservation and the suppression of illegal border trade. Given that the majority of the remaining leopard range in most countries is in borderlands, transboundary collaborations would foster the persistence of small but important populations of Asian leopards.

Acknowledgements We thank S. Karryeva, E. Askerov, H. Raza, O. Pereladova, B. Lortkipanidze, Y. Ilemin, T. Rosen, M. Kabir, N. Jahed, M. Gritsina and A. Gasparyan for contributing data on the legal status of the Persian leopard, Z. Islam for data on the Arabian leopard, and G.R. Clements, A.J. Lynam, and H. Naing for help with collecting data on the Indochinese leopard. MSF was supported by a research fellowship from the Oxford Martin School at the University of Oxford.

Author contributions Study design: MSF, DWM, data collection and analysis: MSF, SR-G, LF, JFK, AS, ES, MA-D; writing: all authors.

\section{Conflicts of interest None.}

Ethical standards This research abided by the Oryx guidelines on ethical standards.

\section{References}

Askerov, E., Talibov, T., Manvelyan, K., Zazanashvili, N., Malkhasyan, A., Fatullayev, P. \& Heidelberg, A. (2015) South-Eastern Lesser Caucasus: the most important landscape for conserving the Leopard (Panthera pardus) in the Caucasus region (Mammalia: Felidae). Zoology in the Middle East, 61, 95-101.

Askerov, E., Talibov, T., Manvelyan, K., Zazanashvili, N., Fatullayev, P. \& Malkhasyan, A. (2019) Leopard (Panthera pardus) reoccupying its historic range in the South Caucasus: a first evidence (Mammalia: Felidae). Zoology in the Middle East, $65,88-90$.

Avgan, B., Raza, H., Barzani, M. \& Breitenmoser, U. (2016) Do recent leopard Panthera pardus records from northern Iraq and south-eastern Turkey reveal an unknown population nucleus in the region? Zoology in the Middle East, 62, 95-104.

Bischof, R., Brøseth, H. \& Gimenez, O. (2016) Wildlife in a politically divided world: insularism inflates estimates of brown bear abundance. Conservation Letters, 9, 122-130.

Clements, G.R., Lynam, A.J., Gaveau, D., Yap, W.L., Lhota, S., Goosem, M. et al. (2014) Where and how are roads endangering mammals in Southeast Asia's forests? PLOS ONE, 9, e115376.

Falcucci, A., Maiorano, L., Tempio, G., Boitani, L. \& Ciucci, P. (2013) Modeling the potential distribution for a range-expanding species: wolf recolonization of the Alpine range. Biological Conservation, 158, 63-72.

Farhadinia, M.S., Ahmadi, M., Sharbafi, E., Khosravi, S., Alinezhad, H. \& Macdonald, D.W. (2015) Leveraging trans-boundary conservation partnerships: persistence of Persian leopard (Panthera pardus saxicolor) in the Iranian Caucasus. Biological Conservation, 191, 770-778.

Farhadinia, M.S., Johnson, P.J., Macdonald, D.W. \& Hunter, L.T.B. (2018) Anchoring and adjusting amidst humans: ranging behavior of Persian leopards along the Iran-Turkmenistan borderland. PLOS ONE, 13, e0196602.

Farhadinia, M.S., Maheshwari, A., Nawaz, M.A., Ambarli, H., Gritsina, M.A., Koshinin, M.A. et al. (2019) Belt and Road
Initiative may create new supplies for illegal wildlife trade in large carnivores. Nature Ecology \& Evolution, 3, 1267-1268.

Feng, L., Shevtsova, E., Vitkalova, A., Matyukhina, D., Miquelle, D., Aramilev, V. et al. (2017) Collaboration brings hope for the last Amur leopards. Cat News, 65, 20.

Hannah, L. (2010) A global conservation system for climate-change adaptation. Conservation Biology, 24, 70-77.

Helsingen, H., Myint, S.N.W., Bhagabati, N., Dixon, A., Olwero, N., Kelly, A.S. \& TAnG, D. (2015) A better road to Dawei: protecting wildlife, sustaining nature, benefitting people. World Wildlife Fund, Yangon, Myanmar.

Hodgetts, T., Burnham, D., Dickman, A., Macdonald, E.A. \& Macdonald, D.W. (2019) Conservation geopolitics. Conservation Biology, 33, 250-259.

IUCN SSC Cat Specialist Group (2016) Foot-amputated leopards in the Caucasus. Facebook, 30 May 2016. facebook.com/ 1478766355730648/photos/a.1483954668545150/1713903278883620 [accessed May 2020].

Jacobson, A.P., Gerngross, P., Lemeris, J.R., Schoonover, R.F., Anco, C., Breitenmoser-Wúrsten, C. et al. (2016) Leopard (Panthera pardus) status, distribution, and the research efforts across its range. PeerJ, 4, e1974.

Karlstetter, M. \& Mallon, D. (2014) Assessment of gaps and needs in migratory mammal conservation in Central Asia. In A Report for the Convention on the Conservation of Migratory Species of Wild Animals (CMS) and the Deutsche Gesellschaft für Internationale Zusammenarbeit (GIZ). United Nations Environment Programme/ Convention on Migratory Species Secretariat, Bonn, Germany.

Khorozyan, I. (2008) Panthera pardus ssp. saxicolor. In The IUCN Red List of Threatened Species. Version 2015.1: e.T15961A96947473 iucnredlist.org/species/15961/96947473 [accessed 7 March 2019].

Khorozyan, I., Stanton, D., Mohammed, M., Al-Ra'il, W. \& Pittet, M. (2014) Patterns of co-existence between humans and mammals in Yemen: some species thrive while others are nearly extinct. Biodiversity and Conservation, 23, 1995-2013.

Kiabi, B., Dareshouri, B., Ghaemi, R. \& Jahanshahi, M. (2002) Population status of the Persian Leopard (Panthera pardus saxicolor Podock, 1927) in Iran. Zoology in the Middle East, 26, 41-47.

Knight, M.H., Seddon, P.J. \& Al Midfa, A. (2011) Transboundary conservation initiatives and opportunities in the Arabian Peninsula. Zoology in the Middle East, 54, 183-195.

Linnell, J.D.C., Trouwborst, A., Boitani, L., Kaczensky, P., Huber, D., Reljic, S. et al. (2016) Border security fencing and wildlife: the end of the transboundary paradigm in Eurasia? PLOS Biology, 14, e1002483.

Macdonald, D.W., Johnson, D.D.P. \& Whitehouse, H. (2018) Towards a more natural governance of Earth's biodiversity and resources. Conservation \& Society, 17, 108-113.

Maharramova, E., Moqanaki, E.M., Askerov, E., Faezi, S., Alinezhad, H., Mousavi, M. et al. (2018) Transboundary leopard movement between Azerbaijan and Iran in the Southern Caucasus. Cat News, 67, 8-10.

McNeely, J.A. (2003) Conserving forest biodiversity in times of violent conflict. Oryx, 37, 142-152.

Moo, S.S.B., Froese, G.Z.L. \& Gray, T.N.E. (2018) First structured camera-trap surveys in Karen State, Myanmar, reveal high diversity of globally threatened mammals. Oryx, 52, 537-543.

O’Kelly, H.J., Rowcliffe, J.M., Durant, S.M. \& MilnerGulland, E.J. (2018) Robust estimation of snare prevalence within a tropical forest context using N-mixture models. Biological Conservation, 217, 75-82.

Oswell, A.H. (2010) The Big Cat Trade in Myanmar and Thailand. TRAFFIC Southeast Asia, Malaysia. 
Perez, I., Geffen, E. \& Mokady, O. (2006) Critically Endangered Arabian leopards Panthera pardus nimr in Israel: estimating population parameters using molecular scatology. Oryx, 40, 295-301. QGiS Development Team (2017) qgis.org [accessed 24 June 2017]. Rostro-García, S., Kamler, J.F., Ash, E., Clements, G.R., Gibson, L., Lynam, A.J. et al. (2016) Endangered leopards: range collapse of the Indochinese leopard (Panthera pardus delacouri) in Southeast Asia. Biological Conservation, 201, 293-300.

Rostro-García, S., Kamler, J.F., Clements, G.R., Lynam, A.J. \& NAIng, H. (2019) Panthera pardus ssp. delacouri. In The IUCN Red List of Threatened Species 2019: e.T124159083A124159128. dx.doi.org/ 10.2305/IUCN.UK.2019-3.RLTS.T124159083A124159128.en [accessed 15 December 2019].

Spalton, J.A. \& Al Hikmani, H.M. (2014) Arabian Leopards of Oman. Stacey International, London, UK.

Stein, A.B., Athreya, V., Gerngross, P., Balme, G., Henschel, P., Karanth, U. et al. (2016) Panthera pardus (errata version published in 2016). In The IUCN Red List of Threatened Species 2016: e.T15954A102421779. dx.doi.org/10.2305/IUCN.UK.2016-1.RLTS. T15954A50659089.en [accessed 31 July 2019].
Troumborst, A., Blackmore, A., Boitani, L., Bowman, M., CAdDell, R., Chapron, G. et al. (2017) International wildlife law: understanding and enhancing its role in conservation. BioScience, $67,784-790$.

Vitkalova, A.V., Feng, L., Rybin, A.N., Gerber, B.D., Miquelle, D.G., WANG, T. et al. (2018) Transboundary cooperation improves endangered species monitoring and conservation actions: a case study of the global population of Amur leopards. Conservation Letters, 11, e12574.

Wang, T., Feng, L., Mou, P., Wu, J., Smith, J.L.D., Xiao, W. et al. (2016) Amur tigers and leopards returning to China: direct evidence and a landscape conservation plan. Landscape Ecology, 31, 491-503.

Wolf, C. \& Ripple, W.J. (2017) Range contractions of the world's large carnivores. Royal Society Open Science, 4, 170052.

WWF (2019) The Dawna-Tenasserim Landscape. World Wildlife Fund. greatermekong.panda.org/discovering_the_greater_mekong/ landscapes/dawna_tenasserim_landscape2 [accessed 9 May 2019].

Zafar-ul Islam, M., Boug, A., Judas, J. \& As-Shehri, A. (2018) Conservation challenges for the Arabian leopard (Panthera pardus nimr) in Western Highlands of Arabia. Biodiversity, 19, 188-197. 